\title{
A Robust Operation: Resettling, Security, and Development in Late Colonial Angola (1960s-1970s)
}

\author{
MIGUEL BANDEIRA JERÓNIMO* \\ E-mail: mbjeronimo@gmail.com
}

\begin{abstract}
The forced removal and resettlement of population was a main feature of late European colonialism, in Africa and elsewhere. Both were crucial to the formulation and enactment of securitarian projects and developmental schemes, and to their recurrent intersection and close interdependence. The repertoires of repressive developmentalism - the shaping of development strategies by securitarian concerns and the contamination of schemes of security by socioeconomic rationales - were diverse, inspiring the various authorities and guiding many specific operations on the ground. This text provides one telling example of these repertoires, the Operação Robusta (1969-1974), which entailed the forced removal of thousands of men, women, and children from the district of North Cuanza to the district of Zaire (both in the north of Angola, under Portuguese rule, and in the middle of an armed conflict that started in 1961), and was seen as a model for similar actions. Assessing the drives and the prospects associated with the operation, this text also addresses its violent dynamics and effects, namely the substantial separation of families, the meagre provision of welfare, and the intense processes of land expropriation.
\end{abstract}

Keywords: decolonisation, developmentalism, Angola, resettlement, colonial war

\section{Envisioning "Trustworthy Natives"}

On 2 April 1969, the Portuguese Conselho de Defesa Militar (Council for Military Defence) decided that another chapter on the overall strategy to combat the widespread colonial insurgencies should be written. Beginning in 1961 in Angola and a few years later also in Mozambique and Portuguese Guinea, the Portuguese authorities had faced multiple challenges coming from local, more or less organised anti-colonial groups, with increasing regional and international support. ${ }^{1}$ These challenges had antecedents (active resistance towards the colonial presence has a long genealogy), but now assumed a more intense and consequential nature. Their local impact was accompanied by international reverberations, and both entailed mounting scrutiny and pressure on the continuation of the Portuguese colonial empire. The empire had been officially dissolved in 
1951, but from that moment on it was tentatively reinforced on many levels (political and economic, essentially), as a result of initiatives for "ethnic colonisation" (the colonisation by white settlers, especially Portuguese), efforts to realise administrative expansion, and an impetus for development and "modernisation."2

In the late 1960s, besides having to deal with many other difficulties, the authorities in Angola struggled to control the northern border of the "overseas province." The vigilance and control over the so-called Sector of Zaire (a military district in the north of Angola), in which the mobility of anti-colonial groups across frontiers was recurrent and hard to curtail, was seen as crucial. ${ }^{3}$ As in many other geographies and moments in time, borderlands and frontiers significantly shaped the contours of colonial rule. This was even more so in a context of open conflict, in which the apparatus of administration was patently small and fragile and the opposition forces were notoriously mobile, in an area scarcely populated, in which the significant circulation of goods, people, and armament was hardly controllable. ${ }^{4}$ Shutting down the frontier had been declared a goal in 1964 , although the impracticality of achieving this intention was quickly acknowledged by many. On 29 December 1964, a plan was formulated by the Direcção da Arma de Engenharia (Military Engineering Command) that outlined a "system for organising monitoring and control of the border" aimed at counterbalancing the circulation of human and material resources (including military) that supported the "insurgency" movements and other unwelcome flows across borders (migrant labourers in transit or contraband, for instance). The plan entailed three fundamental elements, which would require eight hundred African workers to implement: a fence that was to be 350 kilometres in length (and reinforced by minefields); a picada (path) that could be used to circulate people and armaments, connected by intermediary sites that could facilitate military support; and, finally, an area five to ten kilometres wide that would enable the authorities to constantly block "infiltrations" of different kinds and purposes. This area was to be organised around new villages occupied by "trustworthy natives." The latter were seen as the main guarantee of the entire plan's effectiveness. The conditions under which this could or would be ensured were not specified. ${ }^{5}$

However, despite the approval of higher institutions such as the Estado-Maior do Exército (Army Staff Corps) and the Ministry of the Army, this grandiose and costly plan never materialised. One of the reasons was surely related to the fact that the enterprise depended on the active, collaborative role of "trustworthy natives" and also on the actual existence of "native" villages that could guarantee the prescribed political and securitarian goals, as sites of population control, in its various dimensions. The operative assembly of the system and its desired impact on the mounting dynamics of conflict were not possible otherwise. The allocation of human and material resources, considerable and expensive as they were, was not enough. The scheme's continued effectiveness and efficiency required the social "recuperation" and "indoctrination" of Africans (that is, their social and moral rehabilitation and their mentality), and their social and psychological control. Their concentration in villages was seen as facilitating such plans. But, among other problems, the Zaire district was an area with a low population density. The pool of potential reliable collaborators was inadequate, not only in quantitative terms. 
Moreover, the processes of (induced or forced) resettlement, as preconditions for success, were not easy to organise or turn into a stable reality. On many levels, in material, (geo) political, and human terms, these were delicate affairs: they required significant human and material resources in a context of rising war expenditures, they could fuel international criticism and local grievances and, last but not least, they could, and probably would, cause human suffering and losses. But the process of resettlement, cooperation by the "natives," their indoctrination and control, and the provision of a modicum of welfare were seen as the sine qua non of the entire project. Risks were high, but the necessities were greater. The 1969 resolution aimed to overcome these difficulties. ${ }^{6}$

The forced removal of thousands of men, women, and children from the district of North Cuanza to the district of Zaire (both in the north of Angola), dubbed the Operação Robusta (1969-1974), was the solution, albeit a partial one. It was a robust operation, probably the most important of its kind in this period in the Portuguese colonial empire. ${ }^{7}$ The use of the name of the species of coffee beans, robusta, which was the fundamental economic asset of the area, was surely significant, in many ways. ${ }^{8}$ Just two examples of the significance of the name chosen for the operation, which was linked to diverse motivations and interests as well as to severe consequences, were its impact on the redistribution of coffee cultivation areas between native and European communities and the related immediate effect on the economics of coffee. Nearly 6,506 persons were relocated from the North Cuanza district: the vast majority to the Zaire district $(5,183)$, a smaller number to |Moçâmedes $(1,323)$ in the south of the country. ${ }^{9}$ In the latter case, around 320 men, women, and children ended up being placed in the prison camp of São Nicolau. The population transfer and resettlement was related to a wider rationale of control and to other geographies of concentration and confinement, which were not exclusive to Angola. In Mozambique, similar processes occurred. ${ }^{10}$

The operation had three stages. In April and May, the first week of June, and in the first two weeks of July 1969, the transfers were connected to broader operations of detention and "recuperation" of local populations occurring at the time, which involved around 11,000 persons. The list of strategic goals was long and multifaceted. First, the transfer to other districts of population seen as "compromised," thus isolating the "enemy" and diminishing the pool of potential supporters. Second, the regrouping of rural populations, minimising dispersion, which in many circles was considered a precondition for social control, economic development, security enhancement, and military efficacy. Third, the destruction of "clandestine ways of life and cultures" to increase the capacity of the colonial administration to better know and oversee "native" social and economic practices, facilitating market reorganisation, labour stabilisation, and collecting taxes, for instance. Fourth, establishing buffer strips, civil and military (if possible both), capable of blocking the infiltration of the "enemy," isolating and attacking the "refuges of guerrilla fighters," that is: search and destroy. Fifth, promoting the constitution of militias of "self-defence," while reinforcing the existing political and administrative structures, turning the entire process into an instrument of expansion of the infrastructural power of the colonial state. Indeed, as elsewhere and many other times in history, war could, and indeed did, trigger state-building. War could, and indeed did, make (colonial) states. ${ }^{11}$ 
In the north, the goal was to "quickly and completely stifle the subversive situation in North Cuanza through the transfer, to other districts, of that part of the population which was traditionally hostile to the Portuguese or committed to the FNLA" (Frente Nacional para a Libertação de Angola). This would, on one hand, deplete the population in areas that were being used as pools of recruitment by anti-colonial movements such as the FNLA and also the MPLA (Movimento para a Libertação de Angola); on the other, it would assign to (and forcefully impose on) resettled populations an important role in the "zone of infiltration" of the northern frontier, increasing the demographic presence and placing the resettled people at the core of projects for the enhancement of vigilance and control in the area. Again, "trustworthy natives" were needed, whether identified or fabricated. Despite being forcefully resettled, they were expected to act as vigilantes and as the guarantors of order. The erection of new villages, which benefitted from the active contribution of the governor of the Zaire district, became an important element of counterinsurgency, replicating, with some noteworthy differences, similar solutions implemented after the events of 1961, the beginning of the Angolan war of liberation, and even earlier. They were envisaged as examples of promoção social (social advancement) and development, an aspect that would supposedly facilitate the adherence of the population to their prescribed social, economic, and, perhaps more important, political roles. The provision of welfare would create vigilantes. The construction of communal infrastructure and facilities, including hygienic (e.g., first aid stations, washhouses, standpipes), religious (e.g., chapels), educational (e.g., schools), economic (e.g., electrification and soil preparation for cultivation), and social (e.g., football fields), aimed to turn these operations into prototypes of developmental colonialism and sites of profound social engineering focused on individual and collective dimensions. They were designed as model villages, adding a securitarian element to interwar projects that had been more focused on medical, demographic, and socioeconomic rationales (not to mention the older "civilizing stations," crucial in the rhetoric and the politics of the scramble for Africa). The projects imagined in the 1940s (some reminiscent of the Jesuit experiments in South America in the early modern period) and those that came to fruition as a response to the events of 1961 found another expression in the late 1960s. As a consequence of the Robusta, five new villages were erected: Banza-Puto, Calambata, Madimba, Quiende, and Quiximba. ${ }^{12}$ A significant number of those forcefully relocated into these villages were children. In Banza-Puto, half of them, or around 1,085, were children, and the situation was similar in Quiende and Madimba. ${ }^{13}$

Taking this context and these dynamics into account, this article maps and analyses for the first time the fundamental motivations and expectations behind Operação Robusta, also addressing the evaluations made by the authorities involved regarding its consequences. Numerous reports which focused on the causes, expectations, perceptions, and consequences of the operation emerged, in which the authorities tried to capture the results of a variety of social and geographical assessments of the transfer process. At the origin, North Cuanza district, and at the destination, the Zaire district, assessments of the Robusta varied. They were far from homogenous or stable over time. This article 
retraces this diversity of positions and arguments, while uncovering the dynamics, the particularities, and the effects of this violent operation, namely with respect to three aspects that affected local communities seriously at their places of origin and of destination: the breaking up of families, the failure to deliver the welfare measures promised in the context of the forced resettlement (development entangled with security), and land expropriation. These aspects show how the presumed solution of particular problems offered by operations of forced removal and resettlement always entailed new difficulties, and a significant human cost. Despite the shortage of human and material resources, Robusta was seen as a model for action for many of those in charge, and was invoked as the example to replicate in the devising of other similar operations. It lasted until the very end of the empire. This article recounts its history.

\section{On Causes and (Immediate) Consequences}

In mid-1969, the assessment of the impact of the Robusta was positive. In the immediate aftermath of the process of forced removal and transfer of African communities, the military authorities praised the "one hundred casualties in the enemy, the capture of six weapons, the destruction of many barracks and the detention of around one hundred individuals." Moreover, "zones of refuge" had been penetrated and destroyed and progress had been made with the desired regrouping of population and the strategy of creating buffer zones. Beside this more narrow military, strategic, and securitarian assessment, the circumstance that the Robusta was related to an "area with an undeniable economic interest" was also highlighted as of critical importance. The fact that the harsh conditions on the coffee plantations with respect to labour relations and wages regularly contributed to local conflicts and support for dissidence was not taken into consideration. Apparently, the only downside was that the dynamics of resettlement were demonstrating "the feeble administrative, policing and sanitary structures" at the places of destination and their patent "insufficiency." If war led to the expansion of the state apparatus, and also to economic dynamism, the operation of forced removal associated with the former often revealed the crude realities of the colonial situation. ${ }^{14}$

Later in the year, Ramiro Ladeiro Monteiro, chief of cabinet of the Services for the Centralization and Coordination of Intelligence of Angola (SCCIA), the institution responsible for the direction of the intelligence apparatus in Angola, produced a secret report in which he summarised the fundamental information provided by the district governors of North Cuanza and of Zaire regarding the "consequences caused by the transference of populations from the district of Cuanza Norte to the Zaire." Both district governors were asked to assess the impact of the massive forced removal and dislocation of population from North Cuanza, namely from the districts of Bolongongo, Quiculungo, Banga, Ambaca, Dembos, and Bula Atumba. According to the data provided by the governor of North Cuanza at the time, 5,456 men, women, and children were taken to Zaire. "Absolute order" prevailed and no "manifestation of resistance" to the operation emerged. Apparently, nothing else of relevance occurred, or mattered. ${ }^{15}$ 
Notwithstanding these words, when required to offer conclusions regarding the consequences of the entire process, the governor refrained from doing so: there was no "unanimity of reactions" and "in many cases doubts and apathy" prevailed. For instance, the forced removal of indigenous populations was assessed differently by the diverse business interests in the district. The farmers apparently supported the measure, as it promised additional social tranquillity and assured that more land would be available. The prospects of expanding their business undoubtedly mattered in their evaluation of the question. The traders were seemingly more concerned with the decrease of profits and also with the negative consequences for their ability to charge what they sold on credit, a common practice that entailed many questionable critical situations. The departure of families in debt had undesirable effects. The departure of future debtors was not a good prospect. The traders understood the securitarian rationale behind the decision to forcefully remove thousands of locals. But given the associated economic and financial costs, they clearly minimised that rationale. These assessments varied geographically, and the statements from the administrators of the councils involved demonstrated precisely that. In Quibaxe (Dembos), the traders were not pleased, in Camabatela (Ambaca) they were in favour of the measure. In Bolongongo, all Europeans, traders and farmers, were markedly in favour, as they considered "all" African populations to be compromised due to antagonist motivations and movements. But, as the council administrator of Bolongongo noted, this unanimous appraisal, which highlighted political and securitarian rationales, concealed common interests of an economic nature: the desire to seize the coffee plantations abandoned by Africans so they could be exploited by the Europeans, for instance through cooperatives. The heterogeneity of positions regarding Robusta amongst the European, mainly Portuguese, communities in North Cuanza did not end there. For example, in Bula Atumba the Europeans were afraid of the actual consequences of the population transfer as it caused "a vacuum propitious to terrorism."16 No one mentioned that the combination of forced resettlement, land grabbing, and hard labour conditions was also causing an exodus on the part of the Africans. ${ }^{17}$

A similar heterogeneity of assessments could be discerned in the perceptions of the authorities about the reaction of African populations to Robusta, because they in part lacked a deeper understanding of local evaluations and interests. According to the governor, the forced removal was welcomed by the Africans because it entailed the termination of "pressure" from the "enemy" for support and collaboration. Robusta saved them from oppression. The reports provided by the council administrators were more nuanced. In Quibaxe, African communities were seen as being "timid and fearful," unsure if they would be able to return to a normal everyday life, nothing more. In Camabatela, they were portrayed as welcoming the transfer, but for a particular reason: those forcefully removed, given their putative proximity with the "enemy," belonged to a specific ethnic group (from Bindo). Ethnic rivalries and the expected socioeconomic gains related to the removal of a competitor explained their acceptance of the measures taken by the Portuguese authorities. In Bolongongo, local African populations were said to express "doubts" about their destiny and also "resentment" regarding their "separation from family." Nevertheless, the administrator reported that "absolute conformism" prevailed. In 
the Quiculungo district, "fear and distrust" was said to coexist with "confidence" in the positive outcomes of the strategy. In the Banga district, the operation was considered unnecessary. An "effort of indoctrination" (mentalização) would have sufficed to appease dissent and counter the unwarranted interference of opponents. In Bula Atumba, "apathy and dissatisfaction" appeared to characterise the ways in which the African community was dealing with the circumstances. ${ }^{18}$

Despite these ambivalences and the acknowledgement of the existence of resentments and grievances by the authorities, which were by no means due exclusively to the operation and had longer and deeper causes, the operation of forced removal was considered to have a "positive impact" by the majority of those involved in producing assessments. Such was the opinion stated in one official parecer (statement) about Ramiro Ladeiro Monteiro's report. The reaction of the affected African populations was interpreted as acquiescent. In the documentation, made three months after the operation, the enemy's activity was seen as being in decline, especially in areas in which Robusta had the most impact. Moreover, it was argued, the actions against the Portuguese authorities in the areas that received the removed population did not grow either. Another aspect singled out was that the operation was not mentioned by the enemy's propaganda. This was highly positive, as the Robusta could "be exploited in their favour" in Angola and abroad. ${ }^{19}$ The circles promoting the worldwide criticism of what was going on in Angola and the other Portuguese "overseas provinces" would surely welcome information about land expropriation, forced displacement and resettlement, family disintegration, and other dynamics related to Robusta. ${ }^{20}$

But the African response to the operation was the subject of other opinions: more cautious, less optimistic, but not necessarily better informed. For instance, Joaquim Carrusca de Castro, inspector at the administration in Luanda and coordinator of the civil side of Robusta, preferred to emphasise the diversity and ambivalence of African reactions, from "apathy and resignation" to "surprise and hate." Perhaps due to this circumstance and sharing his opinion with the administrator of the district of Banga, the inspector favoured a strategy of "Portugalization" and "indoctrination" instead of one based on the forced removal of populations. At the origin, the first option seemed to entail fewer negative consequences. The military and the civil sides of the operation did not coincide completely. The existence of Europeans who were not pleased with the situation, namely the traders, for reasons already noted, including the loss of profits and fear of "empty spaces," contributed to Carrusca de Castro's critical assessment of initiatives involving population transfer. The latter involved one clear risk: they might solve one problem, but they surely created others, both in African and in European communities. Expecting a backlash, he proposed a series of measures to "prevent the deterioration of the situation." 21 The circumstances were far from peaceful, although some statements suggested the contrary. The creation of mobile teams - the brigadas móveis, focused on psychosocial activities and also on "community development" 22 to enhance the desired "indoctrination," the sponsoring of "self-defence" teams (militias) and strategies, the reoccupation of "empty areas" with other groups or communities, or the temporary reinforcement of military presence (that should be of a temporary nature) were some 
of the proposed measures. Also suggested was the enactment of "severe measures against potential plunderers of agricultural areas." Who these plunderers might be was not clearly defined. The district governor of North Cuanza agreed: it was crucial to strengthen policing and the administrative "grid" to tighten the grip of the colonial state. The reason advanced was telling: the usual contacts with the African populations "were in practice reduced to tax collection" and, also, they essentially derived from the interference by the authorities in rural markets and respective trade. The opportunity should be used to change this long-standing state of affairs. For Carrusca de Castro, it was also fundamental to deal carefully with the agricultural areas, namely those related to coffee production, the district's most important economic asset. The effects on property distribution could be hard to deal with. As it was, things were already problematic. ${ }^{23}$

With respect to the consequences on the receiving end of the population transfer process, the district governor of the Zaire was clearly critical. First, the process of resettlement caused numerous "material difficulties." For instance, the erection of the new villages entailed considerable costs. The conditions necessary for their construction and maintenance did not exist. As noted above, this was one example of the ways projects such as Robusta led to the acknowledgement of the weakness of the colonial state's existing infrastructure. Second, the human resources made available to meet the proclaimed social functions of the new settlements were ridiculously inadequate. The promised provision of welfare and of instruments of social advancement, central as they were to the rhetoric of the ongoing policies of resettlement since the mid-1960s, were not easy to deliver. The combination of a long-standing and manifest scarcity of social services with the paucity of means allocated in connection with the resettlement projects, however grandiose they were in intent, had clear consequences. Identifying or cultivating the envisioned "trustworthy natives" was in danger. For instance, regarding the health services, only three rural sanitary agents were appointed to the areas receiving the resettled communities. Furthermore, there was only one physician from the colonial state's health services in the entire district. And the use of military doctors, considered a possibility with an eye to the growing presence of armed forces, was impossible, given their already busy schedules, not least a result of the ongoing violent clashes.

Another example of the paucity of means was the shortage of security forces, namely of the political police (PIDE), seen as crucial to the entire securitarian drive. Who guarded the guardians? The fact that the resettlement areas were seen as problematic and, also, that the forced resettlement process could in itself generate additional grievances and dissent, meant the role of the political police had become vital. Both the "trustworthy natives" and those who were not viewed as such had to be monitored and controlled. Another problem, surely related to the latter, was the absence of records about the political past of the transferred individuals, which impeded any proper population surveillance and control. To the local authorities, this was especially terrifying, as each village had 1,300 to 1,400 resettled individuals, instead of the planned 600 to 800 . The villages were overcrowded, the facilities were meagre, and the means to know, manage, and ultimately transform their inhabitants were inadequate. Naturally, this was seen as a dangerous situation. The shortage of technical staff to actually deliver the promise of 
"recuperation of populations and their economic development," together with the dearth of police resources, added to the fears expressed by those in charge when they assessed the circumstances on the receiving end of the population transfer process resulting from Robusta. $^{24}$

As the governor summed up, the assistance being provided to resettled populations and for erecting the new villages, the supervision of agricultural production, the "control of suspects" (in theory all those transferred were seen as such, partially as a result of the actual lack of information on their past record), and the provision of water and schooling were all clearly "deficient." The success of the ongoing efforts to change this state of affairs and realise the political, social, and economic measures as promised was proving hard to achieve. The promises that had been made to justify the forced removal of thousands of Africans were not being kept. This fact brought unwanted consequences, which were likely to worsen. The "political and subversive contamination" of local populations, namely in the capital São Salvador and in Tomboco, and the exodus of the resettled population to the Democratic Republic of the Congo, adding to the military strength of the União das Populações de Angola (Union of the Angola People, UPA), were particularly feared. At the time, "small incidents" were already a reality in Banza-Puto. The identification of the instigators was proving difficult, given the lack of information about the resettled communities. And the governor was far from "optimistic regarding the possibility of recuperation" of the population of the new villages. The securitarian and developmental measures were closely related and interdependent. They were failing to deliver to the extent promised. But the severe human consequences were a reality. ${ }^{25}$

\section{Endless Tribulations: Fractured Families, Failed Promises, and "Vacant" Lands}

In October 1969, the governor-general of Angola, Camilo Rebocho Vaz, sent comprehensive information on the situation to Lisbon, to the Overseas Ministry. In his dispatch, he echoed the statement made in the official parecer mentioned above, highlighting that the "violent activity" in North Cuanza had diminished after the forced population transfer. It was as if this was the only thing that mattered, despite the human costs of Robusta. ${ }^{26}$ Nonetheless, the Overseas Ministry wanted to know more details about the ongoing efforts to accommodate and provide assistance to the transferred populations. Most importantly, it wanted to receive more information about the "reasons" that led to the separation of members of the same family during the process of forced removal and resettlement. Among other reasons, the escalation of international pressure over the ways the Portuguese authorities were dealing with the conflicts made those in Lisbon particularly interested in the effects of these kind of operations. One of the explanations came from the SCCIA officials in North Cuanza: the selection of those to be transferred was based

only on evidence that they were committed to the "enemy" cause. ${ }^{27}$ Late in the year, Rebocho Vaz secretly addressed the Overseas Ministry again. He wanted to clarify the procedures followed in the transfer and, additionally, to highlight plans for the future. 
The minister continued to request clarification of the entire affair, as it clearly entailed many problems - some potential, some already a reality, as highlighted above. Three aspects were stressed by the governor-general in his response. First, that "despite the obstacles faced," the selection of individuals to send to the Zaire district was done according to their (presumed) commitment to the "enemy cause," reinforcing what was stated by those directly involved in the situation. Second, that the entire population was informed of this criterion, again echoing information coming from the ground. Finally, that the organisation of militias was sponsored by the colonial administration with a view to protecting those who continued to live in North Cuanza, although the governor-general did not specify the reasons why this initiative was considered crucial, given the proclaimed decrease of "violent activity" in the area, as a result of the Robusta. $^{28}$

The continuous assessment of the repercussions of the forced resettlement process in the Zaire district was a major preoccupation at all levels of the imperial and colonial bureaucracy. Its potentially negative effects caused widespread uneasiness. That was the case with the breaking up of families associated with Robusta, for instance. This was understood to be a natural and expected source of dissent and remained a constant cause of apprehension. Contrary to early arguments and explanations, it was recognised that families were also separated due to the process of resettlement: some members were brought to the Zaire district on different days and therefore were placed in different villages. According to the district governor, Carlos Rodrigues dos Santos, this problem was solved in early 1970: families were reunited and settled in the same place. The same did not happen with the families separated at their origin. Carrusca de Castro, based on his direct experience with the entire process, of which he was a coordinator, pointed to some explanations. The most important was that the "sensitive" nature of the operation and the pressure to execute it swiftly did not take obvious circumstances into account. For instance, the only relatives that accompanied the head of the family in the resettlement process were those who were at home on the date and at the exact time of the operation. Moreover, some of the lists prepared by the Security Provincial Directorate (Direcção Provincial de Segurança) of those that should be forcefully removed, given the putative proximity to "enemy" forces, were delivered in some cases "less than 24 hours" before the removal. The separation of families was an obvious, predictable consequence and one that entailed unintended effects in both districts and made the entire process even harder to manage. Coercive social appeasement - the "recuperation"-was certainly harder to achieve. $^{29}$

Despite the recognition of these issues, the requests for reunion were systematically denied by the authorities. At the time, it was stated, over fifty appeals were filed at the district civil administration offices in North Cuanza from persons wanting to go to the new villages in the Zaire district. They wanted to join their relatives. All the appeals were denied. This state of affairs did not please some authorities, and Carlos Rodrigues dos Santos was one of them. This was perhaps natural, given the fact that his region would be negatively affected. For instance, on a trip to Madimba, he was confronted by locals asking for information on the whereabouts of their relatives. As a 
consequence, he criticised the political police and his fellow district governor of North Cuanza for their decisions and also for the absence of a credible justification for rejecting the growing number of appeals. "Ongoing investigations" was not an acceptable reason to deny authorisation for a voluntary move from North Cuanza to the Zaire district when the result was the reunion of a family. This was especially so when Rodrigues dos Santos was aware that no enquiry was being conducted into whether "active subversive actions" had indeed been committed by the transferred individuals. Information on this topic was meagre and, therefore, the "recuperation" of resettled villagers was in jeopardy, as it might prove to be either unnecessary or misguided. ${ }^{30}$

The critical standpoint voiced by the governor of the Zaire district was badly received in North Cuanza. In one communication sent to Luanda, the governor's "unjustified attitude of non-conformism" was denounced. The facts regarding denial of the appeals for transfer by relatives of those forcefully resettled were tentatively clarified, in order to justify the measures taken. Only thirty-six had been filed, of which nine were accepted. The refusals were explained by a securitarian rationale: many of the individuals requesting to be transferred were seen as problematic. Many escaped the authorities during resettlement between Bula Atumba and Quilombo dos Dembos on 20 December 1968. Two of them were shot. The majority of those who escaped were not captured. One, who was named, falsely led the Portuguese military to believe he was leading them towards a barracks of the "enemy." He tried to escape instead and was killed. The SCCIA in North Cuanza answered with counter-accusations: the district governor of Zaire was being "used" by women that were relatives of these individuals. No evidence to support this statement was offered. It was not clear how these women were able to "use" the district governor, through petitions or public complaints, for instance. But given the fact that these women were the ones suffering the most with the hard conditions of the resettlements, it comes as no surprise that they were the ones demanding that their families be reunited. ${ }^{31}$

Rodrigues dos Santos, however, had a point. The lack of transparency, consistency, and direction in the policy being followed had some disturbing consequences. According to him, the governor-general was clear in his instructions to the district governor: no one should be allowed to return to North Cuanza before "peace was a reality" in the region. The meetings of the Provincial Council of Counter-Subversion (PCCS) and of the Military Defence Council recurrently reinforced that principle. But instances such as the Directorate-General of Security (DGS, as the former PIDE was called since 24 November 1969) were less categorical. Expectations of return were being fed and, in one case, there was even a written declaration that stated that the return was not "inconvenient." This situation was causing "disorientation in those transferred." "Hope of an impending return" was spreading. As a consequence, the commitment to the efforts needed to erect new villages and improve conditions in them were decreasing (assuming that they were ever a significant reality). The development of farm lands, so necessary if the population was to remain settled and unrest be successfully suppressed, was imperilled, and the willingness to work declined. The engagement with the entire process of creating model sites of development and security, of searching for and training 
"trustworthy natives," and of controlling insurgents and insurgencies, was halted (even if many statements argued that it was far from having started). As a 1970 report of the local DGS in São Salvador acknowledged, the "ambition of the majority" was to return as soon as possible to their homelands and reunite with their nuclear and extended families. And if there was any hope that that could be the case, the population involved "would never embrace the idea of growing roots" in the new villages. This hope needed to be shattered. $^{32}$

The problem with the families was not the only pressing question that concerned the authorities. The concerns of the ministerial and local authorities over the reaction of those transferred were tackled by the governor-general by providing information about measures to enhance administrative, hygienic, and social assistance activities in all the new settlements. The information was anything but reassuring. According to the governor-general, social assistance was already a reality in the village of Banza-Puto: one female social worker had been working in the new village for three months. In his own words, however, she had "hardly adapted to the current local conditions." Quiximba, Quiende, and Madimba had no social worker. No one was providing agricultural assistance, despite plans to place one foreman in each village. One single veterinary (a member of the military) was available in the entire district of Zaire. Even worse was the situation relating to public works, hydraulic, and electricity services: the district had no engineer and not even a "simple master builder." The administrative official in each village was therefore responsible for building schools, sanitary posts, or wells. There was a larger number of people responsible for education, including existing female teachers, "families of military men," and some teachers coming from Luanda (six in Quiende, five in Banza-Puto, six in Madimba, and seven in Quiximba). In order to deal with the large numbers of inhabitants in the new villages, which as noted had more than double the planned occupancy, the army was required to collaborate in teaching. The security side was even less promising: only one policeman responsible for public security was deployed, in Madimba. This deficit was compensated for to some extent by the presence of troops skilled in light infantry and anti-guerrilla tactics nearby: a Companhia de Caçadores Especiais (elite light infantry) in Quiximba and Quiende and platoons in Madimba and in Banza-Puto. But this was not enough. ${ }^{33}$ As Carrusca de Castro clearly stated early on, the massive and forced dislocation of individuals created "multiple and complex problems." Their "convictions" were one of the sure causes of further difficulties. Other no less significant issues were the "actual ecological and soil-related constraints" in the new areas, which were inferior to the areas the people came from. In his view, the improvement of the situation in North Cuanza entailed "new problems" in the Zaire district. To "minimize or terminate them" would be "extremely hard."34

Another source of problems was related to what were euphemistically called "vacant" lands, which were a direct consequence of the forced removal and resettlement projects. The so-called land problem, or problema de terras, was pervasive and had multiple dimensions. ${ }^{35}$ The topic of the "vacant" lands had already been defined as problematic prior to resettlement. According to the district governor of North Cuanza, this conundrum could not be easily solved. On the one hand, the "faithful" African populations refused to 
settle in the now vacant lands, because they felt they were being granted land that was vacant as a result of "extortion, which would lead to punishments of a magical nature"; on the other, handing these areas over to Europeans would also be perceived as extortion, leading the African communities to believe that the forced removals had another aim, namely, the transfer and expropriation of land rights, once again. As a consequence, the solution should be the transfer of the vacant lands to the Instituto do Café de Angola (Coffee Institute of Angola), a state department created to administer this crucial economic activity in the colony. ${ }^{36}$ But this was not consensual, especially given the pressure that some "natives" were exerting on the Portuguese authorities to be allocated these lands. After all, this was natural behaviour from anyone interested in entering or expanding within a particular economy, individually or collectively, or from someone fighting for land and produce connected to his or her family or community. Despite a previous resolution made at the PCCS, on 26 September 1969, which placed the vacant lands in the hands of the local administrative authorities, the North Cuanza district governor decided that relatives of those who were forcefully removed to the district of Zaire were to be identified and become the new owners of this property. Presumably, this decision was reached in an attempt to minimise the already significant sources of dissent. The governor-general of Angola was not pleased as this policy was contrary to the doctrine otherwise being advocated, which pointed to the redistribution of lands, to be placed in the hands of the colonial administration or of European interests. But this principle was not confirmed by the SCCIA official in North Cuanza. Occupation of the vacant land by relatives and by those backed by "traditional law" was accepted as a possibility at the Provincial Council. However, for different reasons, the appropriate circumstances were not easy to discern. For instance, in Camabatela, the area in which the local population supposedly supported the forced removal because of ethnic rationales, some relatives of those removed were claiming the vacated lands for their own use. An important aspect in this process was that "traders interested in having their old loans repaid" were supporting these attempts. Furthermore, it was not easy in many cases to determine who the actual relatives with a justified claim were. ${ }^{37}$

\section{A Model to Follow}

Despite all these problematic issues - the breaking up of families, failure to deliver on welfare and social advancement promises, and discriminatory redistribution of "vacated" lands, by mid-1970 Operation Robusta was being regarded as a model that should be emulated. Some of its consequences were praised. In a meeting of the PCCS, the chief of police in the district of Zaire argued that the transferred populations were being openly welcomed by local African communities, as the cases of the village of Banza-Puto and the nearby neighbourhood called Dr. Joaquim de Oliveira purportedly demonstrated. Despite the critical remarks made in 1969 regarding the existence of problems in Banza-Puto as noted above, one year later the situation was declared to be significantly different. ${ }^{38}$ One of the reasons advanced to explain why local populations 
welcomed the arrival of those forcefully resettled was that the process led to an increase in available manpower. Therefore, the persistent requests for labour by the Europeans diminished slightly, and this was appreciated by many. The "psychological state" of the people transferred was seen as being satisfactory. It was argued that the order and security provided in the area was far better than in North Cuanza. Moreover, efforts were being made to avoid turning the new villages into "concentration camps," said the chief of police in the district of Zaire. Isolation and exclusion was not an option. Some efforts to "integrate" the newcomers into local society were being made: they were being hired to do some low-level jobs in the public and private sectors. Despite reports of "small incidents" one year earlier, the behaviour of those resettled was now praised. They were now described as "active" in the process of building new communities and "respectful" of political, securitarian, and socioeconomic aspirations. As a consequence, so far no "police repression" was needed. The district governor, Rodrigues dos Santos, was more careful, pointing to the fact that the people had been resettled for a reason: they were "infiltrated" by anti-colonial movements, namely the MPLA. Their integration was a "calculated risk," which should continue but constantly be submitted to close supervision. The now committed "natives" were far from being reliable. Nonetheless, despite evidence of the shortcomings of the operation, the Robusta resettlement process was seen as having beneficial results, namely, an increase in security and the creation of conditions for a modicum of development. ${ }^{39}$

In another document that evaluated the "collaboration with the enemy" at the time, Robusta emerged as the best path to follow, given the "impossibility" of surrounding - that is controlling and transforming at the same time-the targeted communities on site with sufficient military forces, as a sine qua non for the obstruction of contacts between them and the "enemy." The forced removal of the population from many zones in North Cuanza and involuntary resettlement in other areas should be reinforced. Reports of a marked increase of cases in which the African population was seen as cooperating with the anti-colonial "subversive" forces made forced removals seem even more appealing. For instance, in 1970, in the village of Quibaxe in the Dembos Council, around eighty persons were deemed eligible for immediate transfer. The situation was becoming "dangerous." The costs of the operation were to be covered by "products from the abandoned agricultural lands," as a telegram issued by the governorgeneral's office stated in July $1970 .{ }^{40}$ Frequent news of violent events against military and civil forces in the area-from ambushes on roads to open attacks on farms, such as those on the Ciriaco plantation or the plantation of António Luís (administrative post of Aldeia Nova, Banga Council) - and the assessment that such actions were being carried out with the "support and protection of the villages," which were "apparently peaceful," made the solution provided by Robusta appear extremely tempting. Its "beneficial effects" needed to be replicated and were. All those located in Máua, Camame, Quiage, and Aldeia Nova, a total of 2,963 individuals, were to be transferred out of the district. ${ }^{41}$

From the administrative post of Camame, 816 "souls" were sent to the Regedoria Dalaceia. They were thought to have been involved in an ambush on the road from 
Camame to Banga, in the Council of Golungo Alto, in which a European was killed. The role of the local villagers in the attack was considered decisive. Moreover, given the existent "kinship ties," these supportive activities would surely continue. Accordingly, the villagers were informed that their resettlement was sem apelo, nem agravo (irrevocable, without appeal). In Regedoria Dalaceia, they were temporarily housed in sheds and there were plans to provide some farm lands for their subsistence. From the administrative post of Máua, 292 "souls" were about to be transferred in April 1970, with the "utmost urgency," as a consequence of the violent attacks on the Ciriaco plantation and the property of Francisco Machado Covas that occurred in the same month. The conclusions were similar: it was obvious that the local population had colluded with the rebels and was likely to do so again. Its forced transfer was therefore considered urgent. Another example was the planned transfer of two entire villages, Camongua and Mulungo, to the area of Quiage. The military forces were in favour of this solution, which entailed the resettlement of 780 "souls" into a place encircled by barbed wire. The estimate was that ten kilometres of barbed wire would be needed to do the job. But the major obstacle was seen as residing elsewhere. The resettled villagers needed to be escorted to their farm lands by the military almost every day, especially after the beginning of the coffee harvest, and this was not possible. The ongoing military operations were frequent, and the authorities could not guarantee the surveillance and protection needed. As a consequence, despite being seen as fundamental from a securitarian point of view, the possibility of resettlement under consideration was perceived as risky by the local administrative authority. But nonetheless, Robusta was an example to follow. ${ }^{42}$

In order to minimise the disruptions caused by all the processes of forced removal and resettlement of population, recurrent initiatives of "psychological action" were needed. For instance, the administrative authority in the Dembos Council proposed that a committee formed by the council administrator, a priest from the Catholic mission in Quibaxe, the so-called Prince of Dembos, and some traders should visit the people who had been forcefully transferred to the Zaire district. The solution was approved, with one caveat: the traders must be excluded, as their trip could have something to do with the goal of exerting pressure on those relocated as a consequence of persisting debts. Banza-Puto, Quiende, and Madimba were selected to be visited first. ${ }^{43}$

In March 1971, the district governor of North Cuanza, Pereira de Matos, also visited the villages created in Zaire as part of the Robusta. In Quiximba, the consequences to the disrupted families were still manifest. The majority of those forcefully resettled in the new village were women and children. The explanation for the missing men was twofold: they had been either killed during Robusta or, if able to survive, they had escaped into the "bush." The situation was problematic, but no clear, convincing solution was available. Rodrigues dos Santos proposed that the men who finished their sentences in the prison camp of São Nicolau (southern Angola, in the Namibe Province), could be resettled in Quiximba, if they were not welcomed in their homelands. From São Nicolau, the harsh "recuperation" camp for political prisoners located in the desert, to the new villages: this was the trajectory recommended by the governor of the Zaire district. ${ }^{44}$ 
But, as expected by many, not least by Carrusca de Castro, the resettlement process and the erection of new villages did not end the dynamics of collaboration with anti-colonial movements. For instance, in Madimba the situation was obvious to the security forces and to the governor of the Zaire district. Enquiries were made and the results were not good: around thirty individuals were maintaining contact with the "enemy" and supplying provisions, among other things. It was also admitted that the "enemy" regularly visited the village during the night. "Similar problems" were expected elsewhere. In part, this was considered a consequence of the "deficient control" of the resettled communities by the local authorities, civil and military. According to the governor, the "bad quality" of the chefes-de-posto (heads of local administrative posts) was such that these problems were not surprising. The recent opening of positions in public administration, which aimed to increase the available staff, did not solve a thing. An internal document authored by the administrator of the Council of Santo António do Zaire, Arnaldo Pereira da Silva, stated that new public servants were "incompetent, unprepared." The increase in cases of ineptitude was so visible that a negative impact on local dynamics was turning into a reality, adding to the problems directly generated by Robusta. ${ }^{45}$

This state of affairs was not exceptional. In the southeast regions of Angola, the situation was similar. The processes of population regrouping and control and the organisation of self-defence were also "unsatisfactory." Militias existed only in "theory." The few available administrative officials were generally considered to be "not that good" and opposed placement in these remote areas; their support for the entire project behind villagization was meagre. The police dimension was also a cause of concern. The Rural Guard (the rural police) provided almost no protection and in many new villages defence was provided by one corporal and three soldiers. In theory, the erection of new villages was seen as a good military and securitarian instrument, and they continued to be planned and actually created. In practice, the associated human and material resources were completely inadequate. The number of villages "without protection" was "huge." The control over the existing populations was "very deficient." For instance, the agricultural areas were far from the barracks and the villages, at times up to thirty kilometres away, making it extremely difficult in the Zaire district, as in the north, to monitor the movement and behaviour of the respective populations. ${ }^{46}$

By June 1973, and despite all the problems recognised by diverse authorities - from scarce and unprepared administrative personnel, limited human and material resources, and difficult securitarian circumstances to ineffective attempts to reduce collaboration between the "enemy" and the "natives" - the Robusta experience continued to be positively assessed. In a long report, the DGS subdelegation in São Salvador, district of Zaire, evaluated the history of the operation. Five years later, the new villages finally had "plumbing, electricity, schools, playgrounds for children, playing fields, shower rooms, churches, a commercial store in each settlement" and the resettled population "lived relatively well," with access to "food commodities in abundance." Twenty-five thousand contos, a large sum of money, had been spent on the operation, including on these improvements. Those in Quiximba (159 men, 342 women, and 744 children) dedicated themselves to agriculture and coffee plantation; those in Banza-Puto (679 men, 
1,007 women, and 598 children) were essentially urban workers in the construction industry and "maids and laundresses of the Europeans"; those in Madimba (462 men, 638 women, and 691 children) worked in agriculture and were allowed to occupy the coffee plantations abandoned in 1961; those in Calambata (70 men, 82 women, and 65 children) and in Quiende (574 men, 750 women, and 760 children) also focused on agricultural labour. They all lived "in peace," with the "support" of the administrative apparatus, including considerable financial backing. ${ }^{47}$

But despite this confident portrait, which avoided mentioning the first five years of the resettlement process, one significant aspect was undeniable: the resettled populations did not share the same evaluation. According to the DGS subdelegation, "so far it has not been possible to [ . . . ] make them believe that they live better" in the villages than on "their own lands." The resettled population "constantly lamented" the fact that their lands in North Cuanza were "good" and that there "they had more money." They refused to "recognize the conditions under which they lived" in Zaire, for instance the fact that their children could go to school when they reached the age of six. And there were plenty of signs of discontent. For instance, people who had the opportunity to go to Luanda for medical reasons failed to return for several months, a result of the local "scarcity of resources" (as the report admitted). Another example was even more troubling: contacts with the "enemy" were a regular occurrence. The population in Madimba was labelled as inspiring the "least confidence." There were few "trustworthy natives" and twenty individuals had been recently imprisoned. Questioning of the resettled villagers revealed that the "majority of the population" maintained regular contact with the "enemy," providing money and food to the independence movements, and possibly even "information about our forces." Madimba was not alone. ${ }^{48}$

\section{The Return}

On 15 July 1974, in a telegram to the governor-general, the district governor of Zaire requested information about the ongoing planning regarding the departure of six thousand persons from the district. The events in Portugal, namely the Carnation Revolution (25 April 1974) that brought the authoritarian regime down, surely triggered the decision to move people back to their homelands. Also in July, the governor-general informed the district governor of North Cuanza that he was going to be contacted by a delegate of the Provincial Settlement Board about an "urgent and extremely important operation," the return of the populations forcefully resettled as a consequence of Robusta. As a document produced by the Provincial Council of Counter-Subversion stated, also in July, "the current circumstances" meant that this should take place "as soon as possible." The PCCS took over the planning of the entire operation. Groups of four hundred to five hundred individuals, organised according to common destinations and family relations, were to depart from Quiximba by bus. The communities that were in the other villages were to be transferred there. Everything had one particular purpose: to speed up the process. To this end various authorities from several districts were involved. ${ }^{49}$ 
An "urgent enquiry" to the resettled communities was made, to determine their willingness to stay in Zaire or to return to North Cuanza and, if their option was the latter, to find out if they preferred a "quick and total" transfer operation, or one "spread out" over a longer period of time. The prisoners liberated from São Nicolau, now in North Cuanza, were contacted to see if they would go to Zaire and check the living conditions in the villages, and perhaps decide to stay there. As noted before, a considerable amount of money had been spent over a four-year period by the authorities of the Zaire district on the "tremendous" improvement of the conditions offered in the five villages that accommodated the resettled communities. The creation of sanitary and social facilities, chapels, schools, sports areas, the provision of zinc sheets to cover the lodgings or the preparation of lands for cultivation were seen as proof of the commitment of the authorities to improving the villagers' standard of living. These conditions could continue to be useful, it was thought. For those in Zaire, however, the decision was clear: a swift and complete return to their homelands. In twelve trips called "movements" that took seventy-two days, using 266 civil vehicles that covered an estimated 480,000 kilometres, 5,738 persons (3,184 children, 1,593 women, 961 men) were again settled in North Cuanza. During the process there was one birth and one child and a woman in labour died. Mines exploded during the eleventh movement, between Quiende and São Salvador. According to a report made after the events, in October 1974 a special credit of twenty million Portuguese escudos was given to administrative authorities to sponsor activities that could facilitate the return of those populations but also for measures to ensure they would then remain in their former villages. The provision of food and accommodation were part of the package; so were efforts to market coffee that had been produced, some of which had been brought from the Zaire district (more specifically, some seventy-five thousand kilos of Mabuba coffee). ${ }^{50}$

In a newspaper piece published on 5 September 1974, the return was seen as the end of a destructive chapter. The author advocated putting those who had conducted the resettlement, the "criminals of North Cuanza, the military and civic authorities," on trial as an urgent matter. Otherwise, a "slaughter of Europeans," far "more tragic than the one in 1961," would surely occur. The trial should be public, in order for "all Angola to know how the most elementary rights of the moral and human person were violated."51

\section{Conclusion}

The history of the varieties of repressive developmentalism in late colonial contexts is yet to be fully understood. The operations of forced removal and resettlement and the related erection of planned villages - of which Operação Robusta is a telling illustration-were consummate examples of the trajectory of repressive developmentalism that marked the late colonial period in the Portuguese Empire, with similar dynamics in other cases, within and outside the Portuguese imperial framework. Throughout the process, an intricate articulation of processes of securitization of idioms and repertoires of development (the shaping of development strategies by securitarian concerns) and dynamics of 
developmentalisation of idioms and repertoires of security (the contamination of schemes of security by socioeconomic rationales, frequently more in rhetoric than in practice) emerged in many forms. ${ }^{52}$ In Angola, this was apparent from the early 1960s. ${ }^{53}$ By the end of the empire, around two million Africans were regrouped in aldeamentos in Mozambique and Angola and one hundred fifty thousand in Portuguese Guinea. These were publicised as sites of order and progress, security and development (both economic and sociocultural), arenas of social welfare provision and evangelisation. They were spaces where the administration of inequality and difference was tentatively reinvented, although, again, more in theory than in practice. ${ }^{54}$ The processes of resettlement and their multifaceted strategic goals, such as the ones highlighted at the beginning of this article regarding the Robusta, were expressive examples of the cross-fertilisation between security and development. Languages, rationales, and plans of security and development intersected and became interdependent in many instances. Together, they formed a normative and a strategic framework to which many experts and institutions contributed. Diverse authorities embraced this framework and the related rhetoric, frequently ignoring its actual accomplishments and effects. Robusta is a revealing example of these entanglements and these dynamics. Despite the inherent violence, the dubious achievements, and the disruptive, traumatic consequences, it became a model to be replicated elsewhere, multiplying processes of family disintegration, unequal economic and property relations, symbolic and material violence, manifest gendered imbalances, and, connected to all this, social unrest (including in postcolonial societies). ${ }^{55}$ The continuation, and frequently the increase, of the engagement between local populations and the anti-colonial movements also became a reality, contrary to the expectations (and proclamations) of many. This article shows how this happened and why. ${ }^{56}$

\section{Acknowledgements}

This research was co-financed by-Fundo Europeu de Desenvolvimento Regional (FEDER) through COMPETE 2020-Programa Operacional Competitividade e Internacionalização (POCI), and by national funds through Fundação para a Ciência e a Tecnologia (FCT), in association with the research project The Worlds of (Under) Development: Processes and Legacies of the Portuguese Colonial Empire in a Comparative Perspective (1945-1975). (PTDC/HAR-HIS/31906/2017 | POCI-010145-FEDER-031906).

\section{Bibliography}

\section{Unpublished Primary Sources}

Arquivo Histórico-Militar, Lisbon, Portugal (AHM):

- DIV/2/2/184/002

- DIV2/2/127/003

- FO/007/B/46/SSR.3 
Arquivo Histórico Diplomático, Lisbon, Portugal (AHD):

- Ministério do Ultramar, Gabinete do Ministro, Gabinete dos Negócios Políticos, Repartição de Negócios Políticos (MU-GM-GNP-RNP)

Arquivo Nacional Torre do Tombo, Lisbon, Portugal (ANTT):

- Polícia Internacional e da Defesa do Estado (PIDE/DGS), Delegação de Angola, Divisão de informação, $1^{\text {a }}$ Secção

\section{Published Primary Sources}

Estado-Maior do Exército. Comissão para o Estudo das Campanhas de África (1961-1974). Resenha Histórico-Militar das Campanhas de África (1961-1974), 6 vols., vol. 1, Aspectos da Actividade Operacional, bk. 2, Angola. Lisboa: Estado-Maior do Exército, 2006.

Estado-Maior do Exército. Resenha Histórico-Militar das Campanhas de África (1961-1974), 6 vols., vol. 1, Aspectos da Actividade Operacional, bk. 1, Angola. Lisboa: Estado-Maior do Exército, 2006.

Junta Provincial do Povoamento. Brigadas de Promoção e Desenvolvimento Rural. Luanda: Junta Provincial do Povoamento, 1971.

\section{Secondary Sources}

Allina, Eric. "Borderlands, Boundaries, and the Contours of Colonial Rule: African Labor in Manica District, Mozambique, c. 1904-1908." The International Journal of African Historical Studies 36: 1 (2003): 59-82.

António, João. "O micro-crédito como ferramenta para o relançamento da cultura do café na região agrícola do Libolo e Amboim (Angola)." MA diss., Lisbon, Instituto Superior de Agronomia, 2008.

Bender, Gerald. Angola under the Portuguese. London: Heinemann, 1978.

Cann, John P. Portuguese Counterinsurgency Campaigning in Africa 1961-1974. PhD diss., University of London, 1996.

Coelho, João Paulo Borges. Protected Villages and Communal Villages in the Mozambican Province of Tete (1968-1982). PhD diss., Bradford, University of Bradford, 1993.

- "State Resettlement Policies in Post-Colonial Rural Mozambique: The Impact of the Communal Village Programme on Tete Province, 1977-1982," Journal of Southern African Studies 1 (1998): 61-91.

—. "Da violência colonial ordenada à ordem pós-colonial violenta: Sobre um legado das guerras coloniais nas ex-colónias portuguesas," Lusotopie (2003): 175-93.

Coghe, Samuel. Population Politics in the Tropics: Demography, Health and Colonial Rule in Portuguese Angola, 1890s-1940s. PhD diss., Florence, European University Institute, 2014.

Curto, Diogo Ramada, Bernardo Cruz, and Teresa Furtado. Políticas coloniais em tempo de revoltas. Angola circa 1961. Porto: Afrontamento, 2016.

Feichtinger, Moritz. "Villagization": A People's History of Strategic Resettlement and Violent Transformation, Kenya and Algeria 1952-1962. PhD diss, Bern, University of Bern, 2016.

Gerlach, Christian. "Sustainable Violence: Mass Resettlement, Strategic Villages, and Militias in Anti-Guerrilla Warfare." In Removing Peoples: Forced Removal in the Modern World, edited by Richard Bessel and Claudia B. H. Haake, 361-93. Oxford: Oxford University Press, 2009. Jerónimo, Miguel Bandeira. A Diplomacia do Império. Politica e Religião na Partilha de África (1820-1890). Lisbon: Edições 70, 2012.

_. "“A Battle in the Field of Human Relations': The Official Minds of Repressive Development in Portuguese Angola." In Decolonization and Conflict: Colonial Comparisons and Legacies, edited by Martin Thomas and Gareth Curless, 115-36. London: Bloomsbury, 2017. 
- "Ordering Resistance: The Late Colonial State in the Portuguese Empire (1940-1975)." Political Power and Social Theory 33 (2017): 109-28.

—. "Rural (In)securities: Resettlement, Control and 'Development' in Angola (1960s-1970s)."

Comparativ: Zeitschrift für Globalgeschichte und vergleichende Gesellschaftsforschung 27: 2 (2017): 75-97.

—_. "Repressive Developmentalisms: Idioms, Repertoires, Trajectories in Late Colonialism." In Oxford Handbook of the Ends of Empire, edited by Andrew Thompson and Martin Thomas, 537-54. Oxford: Oxford University Press, 2018.

—. "Managing Inequalities: Welfare Colonialism in the Portuguese Empire since the 1940s." In Inequality in the Portuguese-Speaking World: Global and Historical Perspectives, edited by Francisco Bethencourt, 243-60. Eastbourne: Sussex Academic Press, 2018.

— Decolonization." Special issue, Portuguese Studies 29: 2 (2013): 137-276.

Jerónimo, Miguel Bandeira, and António Costa Pinto. "A Modernizing Empire? Politics, Culture and Economy in Portuguese Late Colonialism." In The Ends of European Colonial Empires: Cases and Comparisons, edited by Miguel Bandeira Jerónimo and António Costa Pinto, 5180. Basingstoke: Palgrave Macmillan, 2015.

Jerónimo, Miguel Bandeira, and Hugo Dores. "On the 'Efficiency' of Civilization: Politics, Religion and the Population Debates in Portuguese Africa in the 1940s." Portuguese Studies Review 25: 1 (2017): 179-204.

Mann, Michael. "The Autonomous Power of the State: Its Origins, Mechanisms, and Results." Archives Européennes de Sociologie 25 (1984): 185-213.

Nugent, Paul, and A. I. Asiwaju, eds. African Boundaries: Barriers, Conduits and Opportunities. London: Cassell/Pinter, 1996.

Stucki, Andreas. "“Frequent Deaths': The Colonial Development of Concentration Camps Reconsidered, 1868-1974." Journal of Genocide Research 3 (2018).

- Violence and Gender in Africa's Iberian Colonies: Feminizing the Portuguese and Spanish Empire, 1950s-1970s. London: Palgrave Macmillan, 2019.

Tilly, Charles, "War Making and State Making as Organized Crime." In Bringing the State Back In, edited by Peter Evans, Dietrich Rueschemeyer, and Theda Skocpol, 169-91. Cambridge: Cambridge University Press, 1985.

Waals, W. A. van der. Portugal's War in Angola. Pretoria: Protea, 2011.

\section{Notes}

* Miguel Bandeira Jerónimo is a senior research fellow at the Centre for Social Studies, University of Coimbra, Portugal. $\mathrm{He}$ has been working on the historical intersections between internationalism(s) and imperialism since the nineteenth century, and on the late colonial entanglements between idioms and repertoires of development and of control and coercion in European colonial empires. He is the author of The "Civilizing Mission" of Portuguese Colonialism (c. 1870-1930) (2015), and the coeditor of The Ends of European Colonial Empires (2015),
Internationalism, Imperialism and the Formation of the Contemporary World (2017), and Resistance and Colonialism: Insurgent Peoples in World History (2019). He coordinates the international research project The Worlds of (Under) Development: Processes and Legacies of the Portuguese Colonial Empire in a Comparative Perspective (1945-1975), funded by the Portuguese Foundation for Science and Technology (2018-2021).

1 For the overall process in Angola, see Bender, Angola under the Portuguese; Waals, Portugal's War, and Jerónimo, "A 
Battle." See also Cann, Portuguese Counterinsurgency.

2 The 1951 Constitutional Revision entailed the abandonment of the concept of a Portuguese colonial empire. A "multiracial," "pluricontinental nation" emerged as an imagined polity and the colonies were now overseas provinces. For the overall dynamics see Jerónimo and Pinto, "A Modernizing Empire?"

3 Needless to say, this text is not about this wider and complex dynamics.

4 Allina, "Borderlands, Boundaries, and the Contours of Colonial Rule." See also Nugent and Asiwaju, African Boundaries.

5 See Estado-Maior do Exército, Resenha Histórico-Militar, 539-50.

6 Ibid.

7 The literature on the "colonial wars" in Angola is substantial. Yet, despite the magnitude and the importance of Operação Robusta, the information available is scarce. The existence and significance of similar operations needs to be further researched per se, in Angola and elsewhere, mobilising finer analytical frameworks, which among other things are not a product of nationalist or "local" historiographies or of studies insulated in subdisciplinary fields (e.g., military history). For a good example of a fine and ample analysis, see Gerlach, "Sustainable Violence." For Mozambique, see Coelho, Protected Villages.

8 By 1973, North Cuanza accounted for 39.30 percent of the coffee production in Angola. See João António, "O micro-crédito," 39.

9 The assessment of the colonial wars made by the military in 2006 points to 5,961 resettled individuals (only to the Zaire). Other estimates point to similar figures, 5,988 individuals. See "Reordenamento das Populações. A Operação 'Robusta'1969-74," in Estado-Maior do Exército, Comissão para o Estudo das Campanhas de Africa, 483; AHM, Governor-General Camilo Rebocho Vaz to the Ministry of Overseas, 2 October 1969, DIV/2/2/184/ 002. See also the report by the Governor of the District of Zaire, AHM, 11 November 1969, in "Retorno das populações deslocadas no Distrito do Cuanza-norte no Distrito do Zaire-Op. 'Robusta," Report by Command of Civil-Military Coordination of QG/ CCFAA, 21 October 1974, DIV2/2/127/ 003.

10 There is also reference to " 300 women and children waiting to be transferred" to the camp. ANTT-PIDE/DGS, Delegação de Angola, Divisão de informação, $1^{\text {a }}$ Seç̧ão, P. Inf. 13.42. a/6, Nt 2015. For Mozambique (and also Cuba, 18681898, and Canary Islands, 1957-1958), see Stucki, “"Frequent Deaths."

11 The dynamics, scope, and impact of these operations that directly affected more than 11,000 individuals are yet to be determined and studied. AHM, "Relatório de comando da R. M. A. $\mathrm{n}^{\circ}$ 2/69. Período de 1 de Abril a 30 de Junho," in "Relatórios de Comando e Actividade Militar nas Províncias Ultramarinas," FO/007/B/46/SSR.3/Cx384/Pasta18. For the idea of infrastructural power of the state, still to be fully tested on colonial grounds, see Mann, "The Autonomous Power of the State." For the classic idea "war makes states" see Tilly, "War Making and State Making," 170 (quotation). For the dynamics of colonial statemaking in the Portuguese colonial empire in the period see Jerónimo, "Ordering Resistance."

12 Report by the Governor of the District of Zaire, 11 November 1969, in AHM "Retorno das populações deslocadas no Distrito do Cuanza-norte no Distrito do Zaire-Op. 'Robusta,"' report by Command of Civil-Military Coordination of QG/CCFAA, 21 October 1974, DIV2/ $2 / 127 / 003$. For the "civilizing stations," see Jerónimo, A Diplomacia do Império. For the "model villages" in the interwar period, see Coghe, Population Politics, 311-79. For the return of this idea since the 1940s, see Jerónimo and Dores, "On the 'Efficiency' of Civilization," and Curto et al., Políticas coloniais, 17-57. 
13 "Reordenamento das Populações. A Operação 'Robusta'-1969-74," in Estado-Maior do Exército, Comissão para o Estudo das Campanhas de África, 483.

14 The example singled out was the area of Alto Cuíto, in Moxico (Central Angola), but this is a recurrent feature of the reports. See AHM, "Relatório de comando da R. M. A. $\mathrm{n}^{\circ}$ 2/69. Período de 1 de Abril a 30 de Junho," in "Relatórios de Comando e Actividade Militar nas Províncias Ultramarinas," FO/007/B/46/SSR.3/Cx384/Pasta18.

15 AHD, Ramiro Ladeiro Monteiro, "Reflexos provocados pela transferência de populações do distrito do Cuanza Norte para o distrito do Zaire," secret, 9 October 1969, MU-GM-GNP-RNP-0367-04257.

16 Ibid.

17 Bender, Angola under the Portuguese, 169.

18 AHD, Monteiro, "Reflexos."

19 Ibid.

20 See a collection of texts dealing with the dynamics of internationalisation of the Portuguese late colonial empire in Jerónimo and Pinto, "International Dimensions."

21 AHD, Monteiro, "Reflexos."

22 On this see Junta Provincial do Povoamento, Brigadas de Promoção e Desenvolvimento Rural, and Jerónimo, "Managing Inequalities," 253.

23 AHD, Monteiro, "Reflexos."

24 Ibid.

25 AHM, Telegram by the District Governor of Zaire to the Directorate of Services for the Centralization and Coordination of Intelligence (SCCIA), 2 October 1969, DIV/2/2/184/002.

26 AHD, Rebocho Vaz to Ministry of Overseas, secret, 9 October 1969, MU-GM-GNP-RNP-0367-04257.

27 AHD, Ângelo Ferreira, Director of the Department of Political Affairs, to Rebocho Vaz, 20-10-1969, MU-GM-GNP-RNP0367-04257; AHM, SCCIA-North Cuanza to governor-general of Angola, 14 November 1969, DIV/2/2/184/002.
28 AHD, Rebocho Vaz to Ministry of Overseas, secret, 13 December 1969, "Reflexos provocados pela transferência de populações do distrito do Cuanza Norte para o distrito do Zaire" (1969), MU-GM-GNP-RNP-0367-04257.

29 AHM, Carlos Rodrigues dos Santos to governor-general of Angola, 30 January 1970; Carrusca de Castro, Inspectorate of Administrative Services, Luanda, to the office of the governor-general of Angola, 17 February 1970, DIV/2/2/184/002.

30 AHM, Carlos Rodrigues dos Santos to governor-general of Angola, 30 January 1970, DIV/2/2/184/002.

31 AHM, Information by SCCIA-North Cuanza, 19 February 1970, DIV/2/2/ $184 / 002$. For a recent and excellent comparative work on the role played by women in late colonial violence and developmentalism see Stucki, Violence and Gender.

32 ANTT, Carlos Rodrigues dos Santos to Directorate-General of Security (DGS)Angola, 12 May 1971; Subdelegation of DGS-São Salvador to DGS-Angola, 29 Apri11970, PIDE/DGS-Delegação de Angola, Divisão de informação, $1^{\text {a }}$ Secção, P. Inf. 13.42. a/6, Nt 2015.

33 There is no more available information on these social workers and teachers in the documentation consulted. AHD, Rebocho Vaz to Ministry of Overseas, secret, 13 January1969, in "Reflexos provocados pela transferência de populações do distrito do Cuanza Norte para o distrito do Zaire" (1969), MU-GM-GNP-RNP-0367-04257.

34 AHM, Carrusca de Castro to the office of the governor-general of Angola, 17 February 1970, DIV/2/2/184/002.

35 For more on this issue see Jerónimo, "Rural (In)securities," esp. 90-6.

36 AHD, Monteiro, "Reflexos." The Coffee Institute of Angola, created on 24 August 1961, regulated the market, promoted academic research, and also provided technical assistance to small local producers.

37 AHM, Telegram, governor-general of Angola to district governor of North 
Cuanza, 12 February 1970; SCCIA-North Cuanza to governor-general of Angola, 13 February 1970; Provincial Council of Counter-Subversion (PCCS) to the office of the governor-general of Angola, 19 March 1970, DIV/2/2/184/002.

38 The dynamics of the resettlement villages varied, for instance according to local circumstances (e.g., more or fewer incidence of conflicts) and political and military initiatives, which favoured more or less investment in security and development. There is a great need for more research on everyday village life (marked for example by the presence of many children), its gendered character, the transformation of the villages over time and, also, the villages' local impact (including in post-independence years). Unfortunately, the existing sources are not abundant and lack differentiated information.

39 ANTT, Carlos Rodrigues dos Santos, PCCS-Zaire, 5 June 1970, PIDE/ DGS-Delegação de Angola, Divisão de informação, $1^{\text {a }}$ Secção, P. Inf. 13.42. a/6, Nt 2015.

40 AHM, Américo José Torquado Salvado, Information by SCCIA-North Cuanza, "Collaboration with the Enemy," 20 May 1970; Telegram, office of the governor-general of Angola, 21 July 1970, DIV/2/2/184/002.

41 AHM, Notes by the office of the governor-general of Angola, 14 Apirl 1970, 20 May 1970, 23 July 1970, DIV/2/2/184/002.

42 AHM, Américo José Torquado Salvado, Information-SCCIA- North Cuanza, "Collaboration with the Enemy," 14 Apirl 1970; Mário da Silva Carranca, Administrative Office of the Council of Bula Atumba, to SCCIA, 13 May 1970, DIV/2/2/184/002.

43 AHM, Américo José Torquado Salvado, SCCIA-North Cuanza to office of the governor-general of Angola, 2 July 1970; Office of the governor-general of Angola to SCCIA-North Cuanza, 13 July 1970, DIV/2/2/184/002.
44 AHM, Carlos Rodrigues dos Santos, district governor of Zaire, 17 May 1971, DIV/2/2/184/002.

45 AHM, Carlos Rodrigues dos Santos, district governor of Zaire, to governorgeneral of Angola, 26 September 1972 and 23 October 1972; Arnaldo Pereira da Silva, Office of Civil Administration, governorship of the District of Zaire, to all administrative departments, 11 September 1972, DIV/2/2/184/002.

46 AHM, "Relatório da visita do General Comando-chefe ao sector do CuandoCubango, 13 a 16 Jun 70," in "Relatórios de Comando e Actividade Militar nas Províncias Ultramarinas," FO/007/B/46/ SSR.3/Cx384/Pasta21.

47 Again, much needs to be discovered regarding the social dynamics of these settlements, from gender relations to their impact in local economies, for instance. ANTT, Subdelegation of the DGS in São Salvador, Zaire District, to Delegation of DGS-Angola, 5 June 1973, "Populações transferidas da Op. Robusta," PIDE/DGS, Delegação de Angola, Divisão de informação, $1^{\mathrm{a}}$ Secção, P. Inf. 13.42. a/6, Nt 2015.

48 Ibid.

49 AHM, Telegram, district governor of Zaire to governor-general of Angola, 15 July 1974; Telegram, governor-general of Angola to district governor North Cuanza, July 1974, DIV/2/2/184/002; AHM, Circular by the Provincial Council of Counter-Subversion, 16 July 1974, DIV2/2/127/003.

50 AHM, Report by Ramiro Alves Correia de Oliveira, Command of Civil-Military Coordination of QG/CCFAA, 21 October 1974, DIV2/2/127/003.

51 AHM, "Populações deslocadas," piece signed by Pedro Bilungi, 5 September 1974, Luanda, DIV2/2/127/003. It is not clear where it was published.

52 Despite this similarity in the manifestations of repressive developmentalisms, there was a clear and significant difference in their chronologies. By the time the 
Portuguese authorities embraced the tentative articulation of processes of securitization of idioms and repertoires of development, their justification was discredited elsewhere. Jerónimo, "Repressive Developmentalisms." For other examples, see Feichtinger, "Villagization."
53 For more on this, see Jerónimo, "A Battle in the Field of Human Relations."

54 Jerónimo, "Managing Inequalities."

55 Coelho, "State Resettlement"; Coelho, "Da violência colonial ordenada à ordem pós-colonial violenta, 175-93.

56 See also Jerónimo, "Rural (In)securities." 